УДК $371.134+378.147 .111$

\title{
ГАЛИНА ФЕДЮК
}

Львівський державний університет безпеки життєдіяльності

\section{ФОРМУВАННЯ ПЕДАГОГІЧНОЇ МАЙСТЕРНОСТІ ВЧИТЕЛЯ В КОНТЕКСТІ ОСОБИСТІСНО ОРІЄНТОВАНОГО ПІДХОДУ}

\begin{abstract}
Розкрито особливості особистісно орієнтованого навчання в педагогічних 3В0, спрямованого на формування педагогічної майстерності й актуалізацію активності студентів як суб’єктів освітнього процесу та подальшої неперервної самоосвіти. Педагогічна майстерність - це вищий рівень педагогічної діяльності, що виявляється у творчості вчителя, постійному вдосконаленні мистецтва навчання, виховання та розвитку учнів. Ї̈ формування передбачає ефективне управління навчально-пізнавальним і виховним процесом, заснованим на варіативних формах педагогічного впливу, діагностиці та самодіагностиці рівнів професійної підготовки студентів.
\end{abstract}

Ключові слова: педагогічна майстерність, учитель, особистісно орієнтований підхід, професійна підготовка, вищі навчальні заклади.

Постановка проблеми. Серед провідних чинників, які зумовлюють ефективність навчання, виховання та розвитку підростаючого покоління на початку XXI ст., визначна роль, безперечно, належить учителю, який реалізує культурно-духовний зв'язок поколінь, виступає гарантом суспільного поступу. Задовольнити соціальні запити і потреби освітньої практики нині може лише активний, всебічно компетентний i професійно підготовлений педагог з інноваційним, творчим підходом до вирішення завдань загальної середньої освіти. У зв'язку з цим зростає значення професійної підготовки учителів, вагомість їхніх особистісних якостей і рівня педагогічної майстерності. Перед українськими вищими педагогічними навчальними закладами постає складна та багатоаспектна проблема, вирішення якої передбачає, з одного боку, формування компетентності майбутніх учителів, з іншого, спрямування освітнього процесу на загальнокультурний, інтелектуальний, моральний розвиток особистості майбутнього педагога. У період модернізації освіти, який характеризується оновленням змісту, удосконаленням форм і методів організації навчання, появою інноваційних технологій, виникає необхідність перегляду методологічних і методичних підходів до підготовки педагогів. Нова науково-педагогічна стратегія має цілеспрямовано проектувати розвиток особистості (Кремень, 2002, с. 19). Сучасна парадигма освіти висуває на перший план особистісно орієнтований підхід до формування майбутнього вчителя, сутність якого виявляється у спрямованості на особистість педагога, реалізацію його власної системи цінностей у професійній діяльності.

Традиційна система підготовки вчителя, хоч і відносить до пріоритетних завдання розвитку його особистості, переважно орієнтує на базові потреби. Однак нині вчитель має бути фахівцем високого рівня: висококомпетентним у предметній галузі; здатним забезпечувати варіативність змісту освіти; готовим упроваджувати в навчальний процес сучасні методики і технології навчання, зокрема інтерактивні, діяльнісні компоненти, тренінгові методи навчання, електронні освітні ресурси; володіти різними засобами діагностики рівня розвитку учнівської молоді, вміти проектувати індивідуальні освітні траєкторії учнів; бути готовим неперервно продовжувати власне самовдосконалення. Тобто, актуалізується проблема формування та розвитку педагогічної майстерності майбутніх учителів (кінцевої мети їхньої підготовки) вже у процесі навчання у ЗВО. При цьому, постають завдання вивчення індивідуально-типологічних особливостей студентів, їхньої творчої особистості та проектування змісту педагогічної освіти, який забезпечує всебічний розвиток кожного вчителя. Тому оновлення вищої педагогічної освіти нині потребує, на наш погляд, реалізації особистісно орієнтованого підходу до навчання.

Аналіз останніх досліджень і публікацій. Вивченню проблем удосконалення змісту, форм і методів педагогічної освіти присвятили праці Б. Ананьєв, С. Архангельський, М. Вашуленко, І. Зимняя, В. Краєвський, В. Кремень, Н. Кузьміна, І. Лернер, І. Підласий, В.Сластьонін, В. Сухомлинський та ін. Питання педагогічної майстерності дослідили Ю.Азаров, Ф. Гоноболін, В.Загвязінський, І.Зязюн, А. Макаренко, В.Семиченко, В. Сластьонін, Н. Тарасевич, Г. Хозяїнов, О. Щербаков та ін. Особливості впровадження особистісно орієнтованого підходу в навчально-виховний процес розглядали І.Бех, Т.Дем'янюк, О.Пєхота, С. Подмазін, В.Рибалка, В. Сєріков, М.Чобітько, А. Хуторський, І.Якіманська та ін. Потужний потенціал особистісно орієнтованого підходу розкрито також у працях М. Берулави, О. Бондаревської, О. Вишневського, О. Дубасенюк, О. Пєхоти, Г. Селевка, Н. Тимощук та ін. Однак, незважаючи на тривале дослідження та апробацію в освітянській практиці багатогранна категорія педагогічної майстерності досі тлумачиться неоднозначно. Це заважає чіткому розумінню не лише ї̈ характеристики (структури), а й найбільш важливих чинників, які впливають на 
становлення та розвиток майстерності педагогічних працівників. Попри вагомі розробки та інноваційні процеси, що відбуваються в освіті, реалізація сучасних підходів не отримала належного відображення в методиці викладання навчальних дисциплін в українській вищій педагогічній освіті. Так, обмаль досліджень щодо впровадження ідей особистісно орієнтованого підходу в підготовку майбутнього вчителя у 3 ВО.

Мета статті: розглянути теоретичні та методичні аспекти формування педагогічної майстерності майбутніх учителів у контексті впровадження особистісно орієнтованого підходу в підготовку освітянських кадрів.

Виклад основного матеріалу. У психолого-педагогічних дослідженнях педагогічна майстерність визначають як інтегративну характеристику високої професійно-педагогічної підготовленості вчителя, внутрішньо зумовлену високорозвиненими особистісними якостями (інтелектуальною культурою, особистісною зрілістю, індивідуальним педагогічним стилем, самоактуалізацією), які виражаються в педагогічній інтуїції, професійній компетентності, оптимальному прогнозуванні та випереджальному передбаченні освітніх результатів, творчій діяльності вчителя. У структурі педагогічної майстерності дослідники виокремлюють чотири відносно самостійні, але взаємопов'язані блоки: 1) професійно-педагогічні знання (наукові, професійні, психолого-педагогічна ерудиція тощо); 2) професійно значущі якості (особистісно-ділові, специфічні професійно-педагогічні, розвинене педагогічне мислення, спрямованість особистості тощо); 3) педагогічні здібності; 4) вміння та навички планувати й організовувати навчальновиховний процес, мистецтво педагогічної діяльності (педагогічна техніка, педагогічний досвід, методичне мистецтво, педагогічні вміння тощо). Всі ці блоки у педагога-майстра зінтегровані в єдине ціле.

Значна кількість дослідників характеризують педагогічну майстерність через їі складові - знання, вміння, навички, цінності, якості. Так, О. Щербаков (1967) поєднує у змісті цього поняття також методичне мистецтво й особистісні якості учителя. За твердженням В. Сластьоніна $(1976$, с. 124), «теоретичні знання і засновані на них уміння - це головний, об'єктивний зміст педагогічної майстерності, єдине і загальне для всіх учителів». На думку Ю. Азарова (1985), поняття майстерності включає вміння управляти розвитком учнів; знання духовних цінностей особистості, колективу, групи й уміння збагачувати їх новим змістом; педагогічну логіку, педагогічну техніку та педагогічний такт, а також громадянську позицію педагога. За I. Зязюном (2008, c. 26-29), основними елементами педагогічної майстерності є: гуманістична спрямованість; професійна компетентність; педагогічні здібності (комунікативність, перцептивні здібності, динамізм особистості, емоційна стійкість, оптимістичне прогнозування, креативність); педагогічна техніка (вміння керувати собою й уміння взаємодіяти у процесі вирішення педагогічних завдань).

Таким чином, сутнісна інтерпретація педагогічної майстерності відображена трьома аспектами: особистісне утворення (рівень професійно-педагогічної підготовленості); якісна характеристика педагогічної діяльності (рівень педагогічної вмілості та результативності в її здійсненні); соціально-педагогічне явище (соціально задані вимоги до особистості, рівня підготовки та якості діяльності педагога). Безперечно, погоджуємось із науковцями і практиками, які стверджують, що педагогічні знання, педагогічний досвід та особистісні якості (педагогічні здібності, професійно значущі якості, професійно-педагогічна спрямованість особистості) становлять фундамент педагогічної майстерності (Хозяинов, 1988, с. 73).

Аналіз теоретичних напрацювань із проблеми педагогічної майстерності дає підстави стверджувати, що в науково-педагогічній літературі це поняття розглядають на основі різних підходів та їх поєднань. Зокрема, Н. Кузьміна, І. Харламов та ін. визначають педагогічну майстерність як вищий рівень педагогічної діяльності, роблять наголос на характеристиці професійних умінь педагога, тобто реалізують діяльнісний підхід. Прихильники особистісного підходу до психолого-педагогічних явищ (І. Зязюн, А. Моленко, В. Миндикану та ін.) вказують на провідне місце в педагогічній майстерності соціально та професійно важливих якостей педагога як основним чинникам успішності його освітньої діяльності. Соціальний підхід до розуміння педагогічної майстерності (Л.Бондарук, А. Маркова та ін.) застосовується в межах досліджень професіоналізму педагогічної діяльності та професійної кваліфікації вчителя як об'єктивної вимоги суспільства до педагогічної професії. Представники особистісно-діяльнісного підходу (О.Барабанщіков, I. Видрін, В.Сластьонін, Г. Хозяїнов, О. Щербаков та ін.) розглядають педагогічну майстерність як синтез професійної компетентності та професійно значущих якостей педагога. На наш погляд, нині найважливішим $€$ особистісний аспект, оскільки в ньому виявляються людські якості, психологічні механізми освітянської праці, умови формування особистості педагога, які забезпечують успіх у навчально-виховній діяльності. Зазначимо, що дослідники роблять спроби виділення найбільш істотних якостей із точки зору ефективності педагогічної діяльності, які істотно впливають на результат професійно-педагогічної діяльності та визначають рівень розвитку педагогічної майстерності.

Гуманістична спрямованість педагогічної діяльності полягає в її орієнтації на особистість учня, утвердження найвищих духовних цінностей, моральних норм поведінки і стосунків та передбачає гуманістичний вияв ціннісного ставлення до праці, її мети, змісту, засобів, суб’єктів. Гуманістична спрямованість особистості вчителя означає ставлення до учня як до найвищої цінності, визнання його права на вільний розвиток і прояв своїх здібностей, реалізацію особистісного творчого потенціалу в професійній діяльності. 
Гуманізація освіти, орієнтація на людину, спроби знайти способи оптимального використання невичерпних можливостей особистості свідчать про зміну пріоритетів у царині соціально-педагогічних цінностей. Відповідно до нової, особистісно орієнтованої парадигми освіти навчально-виховний процес максимально спрямовується на формування розвиненої, самодостатньої особистості, пристосованої до швидкозмінних реалій. Навчання має пробуджувати пізнавальний інтерес, спонукати особистість до творчого пошуку, давати змогу бачити свої здобутки і подальші перспективи. Як відомо, центром гуманістичної, особистісно орієнтованої освітньої парадигми є індивід, його потенціал як основа для формування творчої, конкурентоспроможної, здатної до саморозвитку людини (І.Якиманська). Удосконалення професійної підготовки передбачає розроблення педагогічних технологій, спрямованих на реалізацію особистісного підходу в освіті, що можливо тільки одним способом - зробити навчання сферою самоствердження особистості (В. Серіков).

Особистісно орієнтований підхід до навчання та професійної підготовки, наукові основи якого закладені Є. Бондаревською (2000), В.Сєріковим (1998), І.Якиманською (1996) та ін. - це цілеспрямований, планомірний, спеціально організований педагогічний процес, орієнтований на розвиток і саморозвиток студентів, актуалізацію їхніх особистісних особливостей, що сприяє розкриттю потенційних ресурсів майбутнього фахівця. Особистісно орієнтований підхід дає змогу якнайповніше розкрити структуру педагогічної майстерності, виявити основні чинники, що впливають на результативність процесу, а також фактичні напрями його здійснення. Концепція особистісно орієнтованої освіти розробляється від початку 90 $\mathrm{x}$ pp. ХХст. Основний iї принцип проголошує головною фігурою навчально-виховного процесу учня (вихованця, студента). Особистісно орієнтованою в сучасній педагогіці називають освіту, що забезпечує розвиток, передусім, тих якостей особистості, які допоможуть людині зайняти в житті активну, відповідальну професійну позицію на основі усвідомленого цілеспрямованого саморозвитку (Берулава, 2004, с. 3-5).

Особистісно орієнтована освіта розглядає знання, вміння та навички як один із найважливіших, але все ж лише засіб досягнення головної мети - повноцінного розвитку особистості. Це, по-перше, спонукає вважати абсолютною цінністю не знання й уміння, а саму людину; по-друге, забезпечує свободу вибору змісту освіти, задоволення освітніх, духовних, культурних і життєвих потреб особистості, гуманне до неї ставлення, становлення індивідуальності та можливості повноцінної самореалізації в культурно-освітньому просторі. Такий підхід переносить цілі та зміст освіти в особистісний план людини, дає змогу уникнути їх технократичного відчуження, догматизму й авторитаризму. Зважаючи на це, особистісно орієнтована освіта ставить перед викладачами завдання: забезпечити особистісне зростання, розвиток суб'єктивності, саморозвиток учня (студента); інтелектуальний розвиток; формування у свідомості цілісної картини світу. Ї̈ мета, як зазначає Є. Бондаревська, - не сформувати і навіть не виховати, а знайти, підтримати, розвинути людину в людині й закласти в ній механізми самореалізації, саморозвитку, адаптації, саморегуляції, самозахисту, самовиховання, необхідні для становлення самобутнього особистісного образу та діалогічної, безпечної взаємодії з людьми, природою, культурою, цивілізацією (Бондаревская, 2000). Ця мета реалізується у процесі особистісно орієнтованого навчання та виховання, а головним завданням учителя в цьому контексті є гармонійний розвиток і вдосконалення особистості кожного учня. Особистісно орієнтований характер підготовки майбутніх учителів забезпечується: визначенням головної мети освітнього процесу, де пріоритетним чинником $\epsilon$ розвиток особистості; визначенням змісту, методів, форм і засобів навчання 3 урахуванням індивідуальних особливостей і потреб студентів.

На практиці, на жаль, удосконалення навчального процесу в педагогічних 3ВО зводиться до розроблення нових схем навчально-практичного циклу, появи нових дисциплін, що призводить зазвичай до додаткового екстенсивного навантаження студентів. у більшості випадків не приділяється увага вивченню власних особистісних сил, розвитку їхнього потенціалу, зокрема формуванню смислового поля майбутнього педагога. На думку науковців, процес підготовки вчителя у ЗВО може бути якісно покращено, якщо: в центрі дидактичної системи буде покладена особистість студента, його діяльність, психологічні механізми засвоєння знань та формування інтелектуальних і професійних дій; управління навчально-пізнавальним процесом буде засноване на постійному діагностичному контролі за рівнем особистісного та професійного розвитку і саморозвитку студентів та неперервному моніторингу їхніх досягнень; враховуватимуться індивідуально-типологічні особливості кожного студента, стиль його навчальної та професійної діяльності, суб'єктивний досвід, здатність до міжособистісних відносин і професійно значущі якості особистості майбутнього вчителя; у педагогічному процесі, побудованому відповідно до нової парадигми освіти, дотримуватимуться основні дидактичні, організаційно-методичні, психологічні та технологічні вимоги (Lytvyn, 2013, с. 76-77).

3 цією метою для всіх студентів на кожному етапі навчання складається індивідуальна освітня траєкторія, яка, на відміну від навчальної програми, має гнучкий характер, що дозволяє враховувати динаміку особистісного та професійного становлення майбутнього вчителя. Вона містить результати педагогічної та психологічної діагностики професійно значущих якостей особистості студента, які заносяться у його психолого-педагогічну карту. У процесі особистісно орієнтованого навчання викладачі цілеспрямовано мобілізують активність студентів, стимулюють мотивацію навчальної діяльності, особистісного та 
професійного зростання з урахуванням рівня професійної та особистісної підготовки кожного. На практиці оптимальним є комплексне використання різних форм мотивації.

Зміст особистісно орієнтованого навчання будується на основі узгодження інваріантного та варіативного ядра освітньої програми, що дозволяє студентам певною мірою керувати змістом своєї підготовки. Організація особистісно орієнтованого навчання передбачає постійне управління навчальновиховним процесом з метою підвищення ефективності пізнавальної активності студентів і, водночас, надання їм можливостей самоуправління власною професійною підготовкою.

Моніторинг успішності навчального процесу за особистісно орієнтованого підходу передбачає оцінювання рівня загальної та професійної підготовленості студентів, самооцінку своїх навчальних успіхів та експертне оцінювання ефективності результатів навчання. При цьому основними критеріями особистісної та професійної підготовленості майбутніх учителів $\epsilon$ особистісні якості та прояви індивідуального стилю діяльності; ефективність міжособистісних відносин; навчальні здобутки та суб'єктивний досвід; професійно значущі характеристики випускника як компетентного педагога.

Розвивальне середовище, яке виникає у процесі особистісно орієнтованого навчання, повинне мати певні властивості, що забезпечують якісну педагогічну підготовку: гнучкість, тобто здатність освітніх структур до швидкої перебудови відповідно до потреб особистості (ії досвіду, рівня професійної підготовки, ступеня сформованості індивідуального стилю педагогічної діяльності), довкілля, суспільних вимог; залучення студентів до управління самоосвітою і спільної з викладачами побудови індивідуальної освітньої траєкторії на основі діагностики і самодіагностики рівня професійної підготовки; безперервність, яка виражається у взаємодії та наступності всіх освітніх складових на різних етапах професійного становлення студентів; варіативність, що передбачає зміну освітньої системи відповідно до потреби в освітніх послугах та індивідуально-типологічних особливостей студентів; інтегрованість, спрямована на вирішення навчальновиховних завдань шляхом посилення взаємодії та зв'язків усіх складових освітньої системи; відкритість, що передбачає широку участь усіх суб'єктів в управлінні, демократизацію форм навчання і виховання; саморозвиток i саморегуляція навчально-професійної діяльності, засновані на процесах розвитку i саморозвитку особистості, індивідуального стилю іiї навчальної та професійної діяльності; установка на взаємодію та спілкування всіх суб'єктів освітнього процесу, що здійснюється на основі педагогічної підтримки як цілеспрямованої позиції майбутнього педагога.

Під час організації особистісно орієнтованого підходу до підготовки вчителів доцільно спиратися на особистісно орієнтовані технології освіти, враховуючи при цьому специфіку майбутньої професійної діяльності студентів. Технології особистісно орієнтованої освіти:

- допомагають студентам у виборі типу педагогічної поведінки, яка відповідає як їхнім особистим потребам і можливостям, так і потребам навчальних закладів у вирішенні завдань навчання та виховання молоді, сприяють оптимізації навчальної діяльності учнів і студентів;

- дають продуктивні взірці шляхів особистісного зростання, способів і стилів спілкування, ефективних навичок вирішення проблем, які активізують розроблення власних програм саморозвитку та самовдосконалення;

- розвивають у студентів мотиваційну сферу та педагогічні здібності (педагогічний такт, спостережливість, емпатію та рефлексію, вміння впливати на молоду особистість, враховувати індивідуальні та вікові особливості, сприяти формуванню учнівського колективу тощо);

- створюють нові професійні стандарти поведінки, нові способи взаємодії з учнями і студентами як суб'єктами навчально-виховного процесу;

- забезпечують умови для повноцінного прояву та розвитку особистісних і пізнавальних функцій суб'єктів освітнього процесу (Lytvyn, 2013, с. 77).

Застосування на практиці особистісно орієнтованого підходу до підготовки майбутніх учителів засвідчило його доцільність і ефективність. Насамперед, студенти, які проходять професійну підготовку у 3ВО в умовах особистісно орієнтованого навчання, більшою мірою проявляють гуманістичну орієнтацію, особистісну та пізнавальну рефлексію, готовність до розвитку творчих здібностей і пошуку індивідуального стилю педагогічної діяльності. Таким чином, особистісно орієнтовані освітні технології професійної підготовки майбутніх учителів охоплюють управління навчально-пізнавальним і виховним процесом, засновані на діагностиці та самодіагностиці рівнів професійної підготовки студентів, передбачають використання варіативних форм педагогічного впливу, спрямовані на формування педагогічної активності студентів та актуалізацію їхньої активності як суб'єктів освітнього процесу та подальшої самоосвіти та саморозвитку протягом професійної діяльності.

Висновки та перспективи подальших досліджень. Отже, першочерговим завданням в освітній галузі нині $\epsilon$ перехід системи підготовки педагогічних кадрів на новий рівень, випуск майбутніх освітян, які володіють сучасними методиками і технологіями навчання учнівської молоді. Педагогічна майстерність - це вищий рівень педагогічної діяльності, що виявляється у творчості вчителя, постійному вдосконаленні мистецтва навчання, виховання та розвитку людини. Розглянувши сутність педагогічної майстерності, можна стверджувати: це система, яка охоплює всі структурні компоненти педагогічної компетентності, високий 
рівень прояву яких у теоретичній і практичній діяльності сприяє збагаченню загальної культури педагога, розвитку гуманістичної спрямованості, вдосконаленню його творчих здібностей. Високого рівня педагогічної майстерності можна досягти лише шляхом безперервного особистісного та професійного саморозвитку й самовдосконалення педагогічного працівника протягом усієї життєдіяльності.

Посилення гуманітарної спрямованості сучасної педагогічної освіти неминуче веде до впровадження особистісно орієнтованої стратегії навчання, яка зорієнтована на сутність педагогічної підготовки i розкриття творчого потенціалу майбутнього вчителя. Вона сприяє формуванню у студентів індивідуального стилю педагогічної діяльності шляхом врахування потенційних ресурсів особистості та побудови індивідуальної траєкторії навчання студента під час професійної підготовки у ЗВо і подальшої післядипломної освіти. Водночас, пошук нових шляхів організації підготовки вчителів, заснованих на особистісно орієнтованому підході, вимагає змін не лише в цілях, засобах, формах і методах підготовки, а також удосконалення її змісту та технологій навчання для формування компетентного вчителя, готового до творчої професійної діяльності. Лише в цьому випадку забезпечується справжнє оновлення системи освіти.

Попри чималу кількість теоретико-методологічних досліджень, присвячених педагогічній професії, формування особистості майбутнього учителя, становлення його педагогічної майстерності, готовності до педагогічної діяльності потребують подальших наукових і методичних розробок 3 метою розв'язання суперечності між підвищеними вимогами до професійно-педагогічної підготовки і недостатнім науковопедагогічним забезпеченням цього процесу, слабкою розробленістю технологій ії формування. Зокрема, актуальним $є$ уточнення критерії професійної підготовленості майбутніх учителів, а також виявлення психологічних механізмів, що сприяють розкриттю потенційних можливостей студентів і розвитку їхніх педагогічних здібностей.

\section{Список використаних джерел}

Азаров Ю. П. Искусство воспитывать : кн. для учителя. — 2-е изд., испр. и доп. / Ю. П. Азаров. - М. : Просвещение, 1985. - $448 \mathrm{c}$.

Берулава М.Н. Современные модели обучения в свете концепции гуманизации образования / М. Н. Берулава // Гуманизация образования. - 2004. № 2. - С. 3-5.

Бондаревская Е. В. Теория и практика личностно ориентированного образования : монография / Е. В. Бондаревская. Ростов н/Д : изд-во Ростовского пед. ун-та, 2000. — 354 с.

Кремень В. Сучасна філософія освіти і педагогічна наука / Василь Кремень // Педагогіка і психологія професійної освіти. - 2002. — № 4. - С. 11-20.

Педагогічна майстерність : підручник / І. А. Зязюн, Л. В. Крамущенко, І. Ф. Кривонос та ін. ; за ред. І. А. Зязюна. - 3-те вид., допов. і переробл. - К. : СПД Богданова А. М., 2008. - 376 с.

Сериков В. В. Личностно ориентированное образование : поиск новой парадигмы : монография / В. В. Сериков. - М., 1998. - $289 \mathrm{c}$.

Сластенин В.А. Формирование личности учителя советской школы в процессе профессиональной подготовки / В. А. Сластенин. - М. : Просвещение, 1976. - 160 с.

Хозяинов Г. И. Педагогическое мастерство преподавателя : метод, пособие / Г. И. Хозяинов. — М. : Высш. школа, 1988. $-168 \mathrm{c}$.

Щербаков А. И. Психологические основы формирования личности советского учителя в системе высшего педагогического образования / А. И. Щербаков. — Л. : Просвещение, 1967. — 266 с.

Якиманская И. С. Личностно-ориентированное обучение в современной школе / И. С. Якиманская. - М. : Сентябрь, 1996. - $95 \mathrm{c}$.

Lytvyn A. Learner-Centered Approach in Teacher Education / Andriy Lytvyn, Valeryy Solov'ev // Forming and Qualitative Development of Modern Educational Systems : materials digest of the LXIV International research and practice conference (London, september 26 - october 01, 2013) / org. commit. : T. Morgan (chairman) and other. — London : IASHE, 2013. P. $74-79$.

\section{References}

Azarov Yu. P. Yskusstvo vospytbvat : kn. dlia uchytelia. - 2-e yzd., yspr. y dop. / Yu. P. Azarov. - M. : Prosveshchenye, 1985. - $448 \mathrm{~s}$.

Berulava M. N. Sovremennыe modely obuchenyia v svete kontseptsyy humanyzatsyy obrazovanyia / M. N. Berulava// Humanyzatsyia obrazovanyia. - 2004. № 2. - S. 3-5.

Bondarevskaia E. V. Teoryia y praktyka lychnostno oryentyrovannoho obrazovanyia : monohrafyia / E. V. Bondarevskaia. Rostov n/D : yzd-vo Rostovskoho ped. un-ta, 2000. - $354 \mathrm{~s}$.

Kremen V. Suchasna filosofiia osvity i pedahohichna nauka / Vasyl Kremen // Pedahohika i psykholohiia profesiinoi osvity. 2002. 一 № 4. - S. 11-20.

Pedahohichna maisternist : pidruchnyk / I. A. Ziaziun, L. V. Kramushchenko, I. F. Kryvonos ta in. ; za red. I. A. Ziaziuna. - 3tie vyd., dopov. i pererobl. — K. : SPD Bohdanova A. M., 2008. — 376 s.

Serykov V. V. Lychnostno oryentyrovannoe obrazovanye : poysk novoi paradyhmы : monohrafyia / V. V. Serykov. — M., 1998. $-289 \mathrm{~s}$. 
Slastenyn V. A. Formyrovanye lychnosty uchytelia sovetskoi shkolı v protsesse professyonalnoi podhotovky / V. A. Slastenyn. - M. : Prosveshchenye, 1976. - $160 \mathrm{~s}$.

Khoziaynov H. Y. Pedahohycheskoe masterstvo prepodavatelia : metod, posobye / H. Y. Khoziaynov. — M. : Vyssh. shkola, 1988. - $168 \mathrm{~s}$.

Shcherbakov A. Y. Psykholohycheskye osnovы formyrovanyia lychnosty sovetskoho uchytelia v systeme vыssheho pedahohycheskoho obrazovanyia / A. Y. Shcherbakov. — L. : Prosveshchenye, 1967. — $266 \mathrm{~s}$.

Yakymanskaia Y. S. Lychnostno-oryentyrovannoe obuchenye v sovremennoi shkole / Y. S. Yakymanskaia. — M. : Sentiabr, 1996. - $95 \mathrm{~s}$.

Lytvyn A. Learner-Centered Approach in Teacher Education / Andriy Lytvyn, Valeryy Solovev // Forming and Qualitative Development of Modern Educational Systems : materials digest of the LXIV International research and practice conference (London, september 26 - october 01, 2013) / org. commit. : T. Morgan (chairman) and other. — London : IASHE, 2013. P. $74-79$.

\section{FEDYUK G.}

Lviv State University of Life Safety

\section{FORMATION OF THE PEDAGOGICAL MASTERS OF THE TEACHER IN THE CONTEXT OF A PERSONALIZED ORIENTED APPROACH}

The article deals with the features of learner-centered education at the university focused on the effective management of learning and educational process. This technology is based on varied forms of pedagogical influence, diagnosis and self-diagnosis of levels of students' professional training and it involves forming and updating pedagogical skills of the students' as active subjects of educational process and the following continuous self-development. Teacher training is now regarded as the process of becoming his personality, the development of general and vocational pedagogical culture and the formation of the foundations of pedagogical mastery. On the foundation of research of methodological and psychological and pedagogical bases of professional training of teachers, as well as theoretical and practical aspects of pedagogical education, the content and structure of the scientific concept "pedagogical mastery" are analyzed. Pedagogical mastery is a higher degree of pedagogical activity, which is manifested in the creativity of the teacher, the constant improvement of the art of teaching, upbringing and development of pupils.

Tasks of universities in relation to the formation and development of pedagogical skills of future teachers and improvement of teachers-practitioners in the context of the tasks of the new Law of Ukraine "On Education" - to form professional qualities in them: scientific outlook, moral consciousness, aesthetic views; emotional-sensory, intellectual and volitional activity; psychophysiological readiness; pedagogical cycle, style and manner of behavior; possession of relevant psychological and pedagogical knowledge, the ability to organize educational work, educational activities, participate in research work, creative pedagogical search for the formation of key competencies of pupils; the ability to continuous self-improvement. The optimization of future teachers' training aimed at further research of scientifically grounded changes in the organizational structure of the management of the educational process, its forms and methods, which should be applied in the process of reforming higher education and teacher education system.

Keywords: pedagogical mastery, teacher, personally oriented approach, training, universities.

Стаття надійшла до редакції 11.03.2018 p.

УДК 371.124

\section{I. ФIPСОВА}

Центральноукраїнський державний педагогічний університет імені Володимира Винниченка, м. Кропивницький

\section{ПРОФЕСІЙНА СОЦІАЛІЗАЦІЯ МАЙБУТНЬОГО ВИКЛАДАЧА-ПЕДАГОГА}

У статті автор розкриває сутність та зміст поняття «професійна соціалізація особистості». На основі теоретичних узагальнень дає визначення «професійної соціалізації майбутнього викладачапедагога», висвітлює окремі особливості її інтенсифікації.

Ключові слова: особистість, соціалізація, професійна соціалізація, професійна соціалізація майбутнього викладача-педагога

У сучасному світі змінюються структурні конструкти соціального простору об’єктивної соціалізації. Основною особливістю такого $€$ визначальний потенціал соціальної зрілості індивідів в умовах нестабільності, невизначеності, що характеризують сучасний стан суспільства, оволодівають реально 